\title{
Infinite Possibilities:
}

\section{The Future of Theological Librarianship}

by Brenda Bailey-Hainer

I t's a pleasure to be with the ANZTLA group in Melbourne today. This isn't my first visit to Melbourne - I attended a VALA conference here nearly 20 years ago. It's amazing to see how much the city has changed since then.

The theme of the ANZTLA conference this year - Past, Present, Potential - really resonated with me. Theological and religious studies libraries have proved to be remarkably resilient over time, and some of the strategies that were used in the past can still be successful today. I have some examples from the U.S. that I will use to illustrate the trends that are impacting theological libraries and

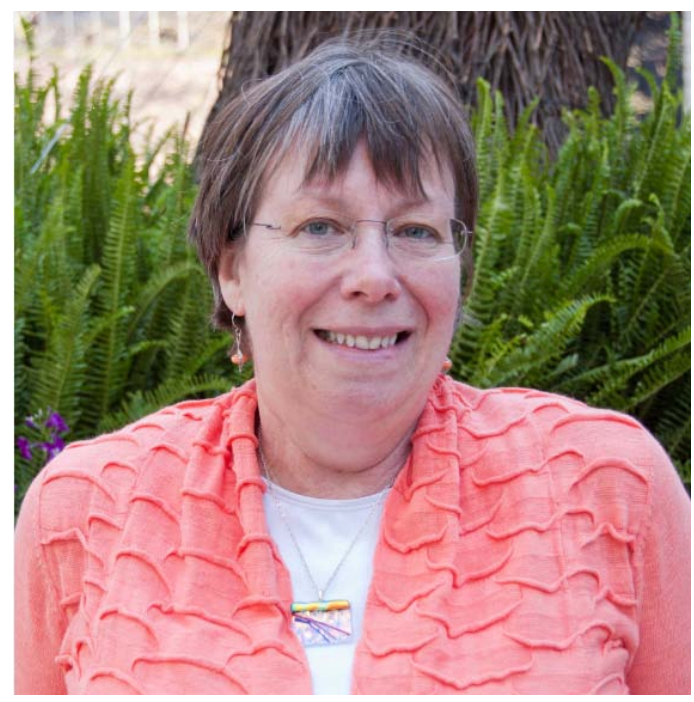
how libraries might cope with future challenges and opportunities.

To talk about how theological and religious studies libraries in the U.S. overcame past challenges is to talk about the history of American Theological Library Association (ATLA) as well. I suspect that all of you are already familiar with ATLA - if for no other reason than you've likely used the research tools that we create and offer through EBSCO Information Services - the ATLA Religion Database ${ }^{\circledR}$, ATLASerials ${ }^{\circledR}$ online full text collection, and most recently the ATLA Catholic Periodical and Literature Index ${ }^{\circledR}$. But you may be less familiar with ATLA as a professional membership association.

A group of theological librarians gathered in the mid-1940s to discuss common concerns. Two of their most immediate concerns were the number of important books in theology that were going out of print and thus no longer available for purchase, and the need for better bibliographic access to scholarly research materials in religion and theology.

Accordingly, they initiated both a preservation project and an indexing project. Member libraries loaned or contributed monographs and journals from their collections to ATLA, which were used to create microform copies for permanent preservation purposes. Supplying libraries were provided copies of the microforms for their own use. Revenue from grants and from the sale of copies to other institutions made this preservation project financially sustainable for many years. 
"ATLA still fulfils

those purposes

as a professional

membership

organization that

creates continuing

education and

professional

development

opportunities

for its members,

including an annual

conference, online

webinars, and

support for regional

workshops."
On the indexing side, The Religion Index was started using volunteer librarian indexers. Gradually the work was taken over by staff employed at ATLA headquarters, and it was transitioned from print to CD-ROM and finally to an online database.

The theological librarians felt that it was valuable also to continue the professional meetings on an annual basis for networking and professional development. ATLA still fulfils those purposes as a professional membership organization that creates continuing education and professional development opportunities for its members, including an annual conference, online webinars, and support for regional workshops.

These early members of ATLA solved their problems through collaboration and prepared themselves to deal with as yet unforeseen new ones through continual learning experiences and networking.

Let's look now at the current situation. The term "theological library" or "religious studies library" may evoke a very different image for each of you. If you are from the United States and work at a divinity school library located on the campus of a large university, it might look like the library space at Duke University's Divinity School Library. Or if you are at another type of university that has a Theology and Religious Studies Department like Seattle University, it might look more like a typical university library that is highly technologically enabled. Or it might conjure up the rich wood and soaring book stacks in the seminary library of your alma mater. And of course it is influenced by the size and shape and structure of the library that you currently work in.

But no matter what your mental image of a theological library is now, it is clear that libraries of the future - and specifically theological libraries - are changing. There are many factors driving these changes. Theological libraries are at the intersection of several fields, and subject to the trends within each of them. I will touch on three major influences on theological and religious studies libraries, and talk about how these are shaping the future.

These are:

1. Trends in higher education generally;

2. Trends in theological education; and

3. Trends in academic libraries.

In addition, I will describe an event that ATLA recently held on the Future of Libraries in Theological Education and talk about the concerns the group identified and their view of the future.

One of the greatest impacts on higher education in the last several decades has been technology. The NMC Horizon Report is an annual collaboration of the New Media Consortium and the EDUCAUSE Learning Initiative. Each year this report identifies and describes emerging technologies likely to have a large impact over the coming five years in education around the globe. This report is useful for examining broader trends because it strives to reflect a contemporary context and the realities of the time both in the sphere of higher education and in the world at large. 
"It goes beyond just the theological studies there, and brings together both students and faculty from a variety of disciplines. It fosters invention, collaboration, and creativity through projects involving $3 D$ design and printing, woodworking, video production, and textile arts."
While some of the report's predictions for technology are clearly blue sky, the trends and the challenges they use to describe the contemporary context are equally or even more interesting. Among the trends cited in the 2014 Higher Education Edition of the report are the increasing use of social media and integration of online and hybrid collaborative learning. Following immediately behind those are the rise of data-driven learning and assessment, and a shift from students as consumers to students as creators. The report also notes that higher education must continue to develop agile approaches to change and that the online learning environment will continue to evolve. ${ }^{1}$

Some of the challenges that were cited in the Horizon Report are echoed in the theological education community - particularly the low digital fluency of some faculty and competition from new models of education. Important developments in higher education technology may be slower to be adopted in our educational environment, but already some institutions have begun to use others - such as 3D printing - as a tool to help students learn better collaboration skills.

For example, at the ATLA Conference in June, there was a presentation from library staff at Abilene Christian University (ACU) called What Would Jesus Hack? They described the "maker" movement, which is a contemporary subculture focused on technology-based approaches to "do-it-yourself" collaboration, fabrication, and distribution of creative projects. ACU has installed a Maker Lab in their library. It goes beyond just the theological studies there, and brings together both students and faculty from a variety of disciplines. It fosters invention, collaboration, and creativity through projects involving $3 \mathrm{D}$ design and printing, woodworking, video production, and textile arts.

It's not just technology that has had an impact on theological librarianship - there is also the changing world of theological education itself. Theological libraries are each closely tied to the specific academic institutions they support, and thus, to theological education in general. Daniel Aleshire, Executive Director of The Association of Theological Schools (ATS), the accrediting body for theological schools in the U.S. and Canada, wrote an article for the journal, Theological Education. Published in 2011, this article called "The Future has Arrived: Changing Theological Education in a Changed World" identifies and analyzes some of the challenges facing theological schools. ${ }^{2}$

One of the most significant changes in theological education has been the introduction of a variety of education delivery modes as schools react to the changing needs of the churches they support

1 L. Johnson et al, NMC Horizon Report: 2014 Higher Education Edition

(Austin, Texas: The New Media Consortium, 2014). http://www.nmc.org/ publications/2014-horizon-report-higher-ed.

2 Daniel Aleshire, "The Future Has Arrived: Changing Theological Education in a Changed World," Theological Education, 2011, 46(2): 69-80. 


\section{"Theological}

\section{libraries can easily}

provide support

for distance or

online education

courses through

electronic resources

available over

the Internet, but

each new degree

program requires

a reassessment

of both print

and electronic

collections. Each

new shortened

timeframe for a

course or degree

program challenges

the library to

intensify and

condense the

research learning

experience." and also to the economic climate. During the last three decades, seminaries have engaged in a broad range of experimentation that has included branch or satellite campuses, new degree programs, electronic delivery of degree programs, shortened or intensive courses, and a host of certificate programs. ${ }^{3}$

Fuller Theological Seminary's Masters in Theology and Ministry (MATM) program is a good example of this experimentation. Students may choose from a variety of options to complete the coursework: face-to-face on campus, combination of face-to-face and online, or primarily online with just three one-week classes on campus. Chicago Theological Seminary now offers 100\% online degrees (MDiv and MA).

Each of these education delivery methods demands a slightly different model of library support, has an impact on the library collection and also on how library services are delivered. Theological libraries can easily provide support for distance or online education courses through electronic resources available over the Internet, but each new degree program requires a reassessment of both print and electronic collections. Each new shortened timeframe for a course or degree program challenges the library to intensify and condense the research learning experience. As the theological school becomes more flexible in the way the education experience is delivered, so must the library be flexible and creative in identifying new solutions such as implementing shared collection development between multiple institutions, embedding librarians in academic departments, or using online chat to answer user questions.

Aleshire noted that North America is increasingly experiencing the influence, interaction and presence of the religions of the world. Globalization has brought multiple religions into close proximity with each other. In the U.S., over $6 \%$ of the population identifies with a religious tradition other than Christianity. This may not appear significant, but in cultures that value individual expression and treat all religions equally, the growth of the world's religions has a greater importance. ${ }^{4}$

Nick Carter, former president of Andover Newton Theological School, has described how as part of a yearlong study, they were forced to conclude that almost every one of the assumptions the school had been founded on was in the midst of being swept away. Andover Newton completely redesigned the curriculum and moved away from a discipline-based curriculum to a competency-based curriculum. They also now include one competency called "Border Crossing" skills, which relates to the ability to minister and witness to ones' faith in a pluralistic world. This reflects a small but growing multi-faith trend of bringing together Christians, Jews, Unitarians,

3 Ibid.

4 Ibid., 72. 
"Aging is a trend among theological librarianship as well. At the time of our last comprehensive survey of ATLA membership in 2010, our demographic analysis showed that $46 \%$ of members were over the age of 55 , but only $14 \%$ under the age of 34. The future lies in recruiting young librarians and seminary students into the profession."
Muslims, and other faiths in a single academy. ${ }^{5}$ Andover Newton now offers interfaith programs in conjunction with Hebrew College and their student body represents over 30 faiths and denominations.

Let me talk now about the changing demographics in theology schools. Denominations that were the foundation of theological education are changing in North America. Assemblies of God have grown, while the Presbyterian Church USA has declined. Evangelical Lutheran Church in America membership has declined and the Southern Baptist Convention plateaued. ${ }^{6}$ A colleague of mine who worked for many years at a Methodist seminary tells me that the average age of a Methodist congregation member is 58 . I know that instinctively when I return to my home church in the small town in Ohio where I grew up and hear discussions of merging congregations or sharing ministers as long term parishioners pass away but are not replaced by young families.

Aging is a trend among theological librarianship as well. At the time of our last comprehensive survey of ATLA membership in 2010 , our demographic analysis showed that $46 \%$ of members were over the age of 55 , but only $14 \%$ under the age of 34 . The future lies in recruiting young librarians and seminary students into the profession. At the ATLA conference in June, we held our regular welcoming event for new members and first time attendees to the conference. I was pleased that we had over 30 individuals who qualified, many of them library school students or recent graduates. There was definitely a new kind of energy at the event this year, including a significant active group on Twitter - a first for ATLA.

In the fall of 2010, more than $24 \%$ of total enrolment at ATS accredited schools was persons of colour. Women and students of colour account for all the growth in enrolment between 1990 and $2011 .^{7}$ Yet, a survey of ATLA members from the same time period revealed that while there is an equitable balance of men and women in theological librarianship, we are lagging considerably behind in recruiting librarians of colour to the profession. Trends in multi-faith discussion in theological schools and the change in the demographic make-up of the student body require that theological librarians must begin to better reflect the communities and the people we serve and launch aggressive programs to recruit people of coloru and other faiths into the profession.

As membership in many mainstream Protestant denominations declines, this impacts enrolment at theological schools which in turn impacts theological libraries. As theological schools have closed and merged, the number of theological libraries has been reduced, resulting at times in a single library serving multiple institutions. These same economic conditions no longer make it practical for the surviving libraries to collect everything published in a discipline "just in case" it is ever needed. Instead, they are moving to a "just in time" approach that takes advantage of ebooks and other electronic formats. Using metadata to describe in their catalogues the materials that could potentially be purchased, the library will increasingly

5 Nick Carter, "Adaptive Leadership: Planning in a Time of Transition,"

Theological Education, 2011, 46(2), 12.

6 Aleshire, 70.

7 Aleshire, 73. 
"The really big breakthroughs that will shape new futures for libraries will occur when people, organizations and ideas come together and work in new ways that encourage risk taking and challenge long time assumptions." acquire only those items that faculty and students actually want to use. This model is often referred to as "patron driven acquisition."

This is a good segue to general trends in academic libraries. The ACRL Environmental Scan 2013 published by the Association of College and Research Libraries division of the American Library Association is an excellent resource for examining trends in community college, four-year college, and university libraries that also apply to theological and religious studies libraries. ${ }^{8}$

The Environmental Scan noted several trends that are already having an impact. Some are from the greater higher education environment such as unbundling of degree programs, the changing demographics of students, the rise of MOOCS, and an increasing interest in digital humanities. Other trends that were cited include creating content through the library serving as a publisher, providing collaborative spaces, and collaboration between libraries themselves. ${ }^{9}$

Collaboration - one of the strategies of the past - is being reinvented in new ways, such as "radical collaboration." The really big breakthroughs that will shape new futures for libraries will occur when people, organizations and ideas come together and work in new ways that encourage risk taking and challenge long time assumptions. This might involve sharing technical services staff between two or more institutions, following models of cooperative collection development, resource sharing, and creating large multiinstitutional, offsite print storage facilities. ${ }^{10}$ The theological library of the future will collaborate regionally and nationally not just with other libraries like itself, but also with organizations that share a similar purpose like the Wabash Center for Teaching and Learning in Theology and Religion or the Forum for Theological Exploration.

Another source for determining trends that impact theological libraries is the librarians themselves and their administrative colleagues on campus. On June 24, I facilitated a conversation that was jointly sponsored by ATS and ATLA. Our focus was to learn about participants' perceptions of libraries and to understand their needs, expectations and visions about the future of libraries in theological education. The group consisted of library directors, chief academic officers, and chief technology officers from twelve theological schools. As part of the application process, each group submitted an essay about their current challenges, issues and concerns and why they wanted to attend the conversation.

A variety of themes emerged from these essays. Online and distance education at theological schools has greatly expanded in the last several years. The biggest concern - almost every essay mentioned this - was how the library can effectively support online

8 ACRL Research Planning and Review Committee, ACRL Environmental Scan 2013 (Chicago: Association of College and Research Libraries, American Library Association, 2013).

9 Ibid.

10 Ibid., 16. 


\section{"Theology and}

religious studies

faculty have

never been among

early adopters, particularly when it

comes to adopting

technology.

However, there is a

growing recognition

of the field of digital

humanities. One

group mentioned

anticipating

"computational

theology" as a

new field that will

apply technological

methods to the

study of theology-

including activities

such as data mining

and text mining." and distance education students in ways that are equitable with oncampus students.

In the U.S. the dwindling size of Protestant congregations has been the partial cause of an increase in the number of bi-vocational pastors, and the group expressed concern about this issue as well. Theology and religious studies faculty have never been among early adopters, particularly when it comes to adopting technology. However, there is a growing recognition of the field of digital humanities. One group mentioned anticipating "computational theology" as a new field that will apply technological methods to the study of theology - including activities such as data mining and text mining. E-books, e-textbooks, digitization of legacy materials and expanding access to electronic versions of theological materials were other concerns. Scholarly communications - including the library as a potential publisher - and support for interreligious dialogue were pre-eminent concerns as well.

In discussions on how these concerns could be addressed, collaboration quickly rose to the forefront as a strategy. This has already manifested itself in several ways. A subset of the ATLA membership is involved in an E-book Lending Project, which is looking at creating a shared e-book delivery platform using Odilo, which is often referred to as the "Douglas County Libraries" model. They are currently in discussions with religion publishers to negotiate better terms and conditions, including an ownership model for purchasing content outright. Another example arose at the recent ATLA conference, where a call was issued to librarians to start a resource sharing group to facilitate reciprocal borrowing among theological libraries across the country.

An interesting insight the group had was in regard to how accreditation standards may continue to reward old behaviours. One chief academic officer bemoaned the fact that he spent his days participating in a system that was designed to be a gatekeeper mired in process.

One of the biggest challenges theological librarians face is supporting different generations of faculty and students. The participants in the Future of Libraries in Theological Education session noted that there is a huge digital divide on the campuses of theological schools. Older faculty members are often still technologically challenged, while a younger generation of faculty is fully digitally enabled. Some recent examples of the new generation of scholars come to mind.

Dr Christopher Cantwell, is an Assistant Professor in the History Department at the University of Missouri - Kansas City, specializing in Religious History. He formerly worked at the Newberry Library in Chicago and taught at the University of Illinois - Chicago. He was also responsible for organizing the first THATCamp (The Humanities and Technology) related to the study of religion. Some 70 people gathered at the American Academy of Religion (AAR) 


\section{"The iBook version} opens with a video and is enhanced in other ways throughout. One of the problems with this model, however, is there is not currently a way for libraries to easily purchase this iBook and make it available to students and faculty in the same way that other ebooks are now available." and Society for Biblical Literature (SBL) meetings for THATCamp in Baltimore last November. An unconference format was used to create an environment to meet like-minded colleagues for exchanging information and learning about applying technology to research in religion.

Dr Kathryn Reklis, Assistant Professor at Fordham University, served as a Research Fellow with the New Media Project, which is now based at Christian Theological Seminary in Indianapolis. The Project is about helping religious leaders become more theologically savvy about technology. She blogged regularly as part of her duties, and has indicated that her blogging experience is one reason why Fordham University was interested in hiring her.

Dr Jacob L. Wright is an Associate Professor of Hebrew Bible at the Candler School of Theology at Emory University. He created an enhanced iBook version of his book, King David and His Reign Revisited, which was recently published by Cambridge University Press. The iBook version opens with a video and is enhanced in other ways throughout. One of the problems with this model, however, is there is not currently a way for libraries to easily purchase this iBook and make it available to students and faculty in the same way that other ebooks are now available. Dr Jacob Wright is also offering an open access Coursera course on The Bible's Prehistory, Purpose and Political Future.

Journals are also being enhanced in new ways through the efforts of young scholars. Dr Emily Suzanne Clark is a recent graduate from the Department of Religion at Florida State University and started this fall as Assistant Professor of Religious Studies at Gonzaga University. While completing her doctoral degree, she served as Managing Editor of Journal of Southern Religion. This is a peer reviewed electronic open access journal which is available via the journal website as well as in ebook format for Amazon Kindle, Apple iOS, and other ereaders and tablets. Their website includes podcasts of interviews with authors.

"Scholarly communications" is a broad-reaching term that may cover a variety of things and for many libraries represents both a thorny issue and an opportunity. Personally, I like the definition in Wikipedia: "Scholarly communications is the creation, transformation, dissemination and preservation of knowledge related to teaching, research and scholarly endeavors."

Open access is one topic frequently talked about in the context of scholarly communications. "Publish or Perish: Academic Publishing Confronts Its Digital Future," an article recently published in John Hopkins Magazine, nicely summarizes the challenges facing participants in the chain of traditional scholarly communications. While there is a clear need to reinvent the way that academia talks to itself, tenure and academic careers are still closely tied to being published in print media. The publishing requirement at universities is in large part what keeps the current economic model for scholarly 
"These types of publishing models, if based on a modest subscription fee, could serve as

\author{
a middle ground
}

between small

society publishers

moving to expensive

commercial

publication and the

other extreme of

all peer reviewed

research appearing

in open access

publications. The

academic library

can - and has

already begun to -

play a significant

role as a scholarly

publisher." publishing going. Open access publishing solves the cost concerns that many librarians have, but isn't necessarily feasible for every publication that currently exists. "Removing a commercial entity from the mix does not remove the need for a publishing infrastructure that includes server space, technicians, and indexers and abstracters who perform the data tasks that support findability - the people who pull journal literature together, assign keywords to articles, and control that vocabulary."11

The digital age has made it easier for libraries to become not just purveyors of information, but creators themselves. Many universities - and not just those supporting theological education - have become concerned about the rising cost of scholarly journals and the feasibility of continuing to purchase them. As a result, a number of university libraries have chosen to become publishers in their own right. The University of South Florida is just one example where, using the Digital Commons model and the bepress platform, they have "rescued" a number of journals that were in danger of fading away or being taken over by commercial publishers. Vanderbilt University, using a different technology platform, began by hosting one journal, and now has begun supporting more, including one title focusing on religion. These types of publishing models, if based on a modest subscription fee, could serve as a middle ground between small society publishers moving to expensive commercial publication and the other extreme of all peer reviewed research appearing in open access publications. The academic library can - and has already begun to - play a significant role as a scholarly publisher.

At the American Theological Library Association, we are taking several steps to grapple with the thorny issues of scholarly communications. This fall, a new task force will begin meeting, The Task Force on Scholarly Communications in Religion and Theology. A large umbrella organization, it will seek to involve representatives from all of the stakeholder groups and tackle issues such as open access, libraries as publishers, tenure requirements, and the rising price of journals. I'm pleased that there are several other groups from the broader field of humanities that are relevant to these efforts. Two examples are Force 11: the Future of Research Communications and e-Research and KN Consulting which recently published a white paper, A Scalable and Sustainable Approach to Open Access Publishing. in the Social Sciences and Humanities. Both of these efforts show that gradual progress is being made in this area.

Seminaries and their libraries echo the need that Aleshire voiced for interreligious dialogue. Both Hartford Seminary and Ecumenical Theological Seminary have Islamic chaplaincy programs, and other institutions such as Harvard, Yale, and the University of Chicago

11 Bret McCabe, "Publish or Perish: Academic Publishing Confronts its Digital Future,” Johns Hopkins Magazine, Fall 2013, http://hub.jhu.edu/magazine/2013/ fall/future-of-academic-publishing. 
"These new roles are challenging because they draw the library director's

attention away

from managing the library. However, it is an opportunity to bring the library more squarely into conversations about finances, curriculum, and research at the highest leadership levels at the academy." have had programs for many years in which students representing many different faiths study side by side.

The library can play a direct role in alleviating potential tensions on campus. Diane van Meter, former library director at Ecumenical Theological Seminary in Detroit, Michigan, has talked about how her library was welcoming to a diverse group of students when the institution initiated a Muslim Chaplaincy program that included both Sunni and Shiite Muslim students. She used a welcoming strategy to help them become comfortable with each other as well as with Christian students on campus. As part of the strategy, the group had potluck meals together in the library to learn more about each other's food traditions.

Although ATLA's roots were with mainline Protestant schools, within ATLA we now have Buddhist, Muslim, and Jewish members. Increasingly we look for commonalities among them all. At our recent conference, we had a panel of speakers from Belgium, the UK, and Kenya, as well as an Islamic scholar from Chicago who herself is Muslim, and a Buddhist monk from Myanmar. All of them talked about the common need for the preservation of and access to manuscripts and special collections to document their religious traditions.

Many library directors at ATLA member institutions are taking on other roles in addition to their traditional library responsibilities beyond just teaching courses part-time. They are now being charged with roles as varied as serving as part-time registrar, head of assessment, or being put in charge of all materials being gathered for the 10-year accreditation report. For example, at Abilene Christian University, the library director's title is "Dean of Library Services and Educational Technology." At Austin Presbyterian Theological Seminary, the title is "Associate Dean for Seminary Effectiveness and Director of the Library." At Vanderbilt University, it is "Associate Dean for Libraries and Director of the Divinity Library" and in reality it involves oversight for the operations of 6 of the 8 campus libraries. At St. Charles Borromeo Seminary in Pennsylvania, the library director has multiple roles and is called "Vice President for Information Services and Assessment." These new roles are challenging because they draw the library director's attention away from managing the library. However, it is an opportunity to bring the library more squarely into conversations about finances, curriculum, and research at the highest leadership levels at the academy.

No discussion about challenges at theological institutions would be complete without talking about digitizing legacy content. Theological and religious studies libraries contain vast quantities of legacy content in print, microform, audio and video formats. This includes valuable unique content that is not easily discoverable or accessible. A 2012 report from ITHAKA S+R, Supporting the Changing Research Practices of Historians, found that these researchers tended to have a foot in both the physical and digital research worlds. 
"The partners

will use the

results of the

survey to explore

collaborative

initiatives to

respond to

identified long-

term collection

care, preservation, and access needs.

This will definitely

include examining

the potential for

digitization of

special collections

housed at these

libraries."
Scholars in the field of religion and theology follow many of the same practices as historians. Although they are willing to travel to special collections for hands-on use of materials, limited travel funds are available to them. Electronic finding aids are helpful for determining which collection would be most valuable to them. Digital images, OCRed materials or transcriptions are also useful when materials from an important figure or about a topic are scattered among many different physical locations. ${ }^{12}$

To solve the issue of findability and access, some theological libraries have fallen back on an old technique that worked for the ATLA members doing indexing back in the mid-1900s: crowdsourcing. One example is the Pitts Library at the Candler School of Theology at Emory University. They are using volunteers to transcribe materials in their special collections, including papers and sermons. ${ }^{13}$

In September 2013, ATLA, along with its partners the Association of Jewish Libraries and the Catholic Library Association, was awarded an IMLS National Leadership Planning Grant, "In Good Faith: Collection Care, Preservation, and Access in Small Theological and Religious Studies Libraries." An advisory committee comprised of members from all three associations was formed and the group has been meeting via phone and in person. A survey which was conducted this spring was designed to help the project partners gain a better understanding of collection care, preservation, and access practices in small theological and religious studies libraries, archives, and cultural institutions and begin to identify valuable and vulnerable collections held in these institutions. Over 240 libraries and archives responded to the survey and included ATLA members, other academic institutions, synagogue libraries, diocese libraries, and archives at a number of Catholic organizations. The partners will use the results of the survey to explore collaborative initiatives to respond to identified long-term collection care, preservation, and access needs. This will definitely include examining the potential for digitization of special collections housed at these libraries.

Let's circle back now to the conversation on the Future of Libraries in Theological Education. At the end of the day the group reflected on what the Library and the Library Director of 2030 will look like. For the future director they looked at specific questions such as: What does the space look like? Where is it located on campus? What is it called? Their group definition included many aspects of libraries that we are already familiar with today. They predicted that

12 Roger C. Schonfeld and Jennifer Rutner, Supporting the Changing Research Practices of Historians (ITHAKA S+R, December 12, 2012), http://www.sr.ithaka. $\mathrm{org} /$ sites/default/files/reports/supporting-the-changing-research-practices-ofhistorians.pdf.

13 Chris Pollett, "Reading Beyond the Lines: Volunteers Increase Pitts' Reach Around the World," (2012), http://www.candler.emory.edu/news/connection/ summer2012/reading-beyond-the-lines.cfm. 


\section{"The beauty of}

libraries is that they transcend the medium in

use at the time

and continue to

evolve. It matters

not whether the

library's collection

is made up of

scrolls or books,

manuscripts

or journals,

physical items

or downloadable

digital objects, or

the technological

method through

which the librarian

reaches out to

students and

faculty. What

matters is that

the library is an

interactive place of

knowledge." the theological library of the future would exist in both physical and virtual space with both print and electronic materials. It will support 24 hour access with both virtual and physical help desks, and utilize embedded librarians in both in-person and virtual courses. Some saw it as a place to obtain media beyond the traditional book and journal formats, and others felt that there might be mergers between libraries and museums where appropriate.

A series of questions was asked about future library directors, such as: What is their educational background? What skills are they evaluated on? There was a split among attendees about what the library director of 2030 will look like. Some felt that a PhD in religion is mandatory. Others saw the role of the director as an expert in organizational leadership with perhaps other degrees needed beyond the traditional MLS or MLIS - for instance, an MBA or a degree in computer science. A few chief academic officers viewed the library director in a PR role or as a revenue generator for the institution.

One of the library directors in his application essay asked "Will the library simply become an abandoned book vault or a glorified internet café..."But later, he answered his own question: “The internet has not killed the library, but has broadened our understanding of the library's role in curating knowledge. It allows religious leaders to skilfully and critically engage with ancient texts and current issues."

While the electronic age has reduced barriers and made the contents of the library available $24 \times 7$ beyond its walls, it is clear that it is difficult to envision the future without a physical library and a librarian. Both physical and electronic resources must have a central location, and a knowledgeable professional is still needed to sort through the plethora of material available to help identify what is most useful to support academic activity in their own environment. The library - whether physical or virtual - is a gathering place for people to meet, to communicate, to collaborate, and contemplate.

Both uncertainty and turmoil lie ahead for theological and religious studies libraries. But there is significant opportunity as well. The beauty of libraries is that they transcend the medium in use at the time and continue to evolve. It matters not whether the library's collection is made up of scrolls or books, manuscripts or journals, physical items or downloadable digital objects, or the technological method through which the librarian reaches out to students and faculty. What matters is that the library is an interactive place of knowledge. This offers us a world of infinite possibilities. The theological library of the future will not be simply a storehouse of information, but a place to enter into dialogue with the vast treasury of theological and religious traditions.

A PowerPoint presentation to accompany this paper can be found as a Supplementary file. 


\section{Bibliography}

ACRL Research Planning and Review Committee. ACRL Environmental Scan 2013. Chicago: Association of College and Research Libraries, American Library Association, 2013. http:// www.ala.org/acrl/sites/ala.org.acrl/files/content/publications/ whitepapers/EnvironmentalScan13.pdf

Aleshire, Daniel. “The Future Has Arrived: Changing Theological Education in a Changed World." Theological Education, 2011, 46(2): 69-80.

Carter, Nick. "Adaptive Leadership: Planning in a Time of Transition." Theological Education, 2011, 46(2): 7-13.

Johnson, L., Adams Becker, S., Estrada, V., Freeman, A. NMC Horizon Report: 2014 Higher Education Edition. Austin, Texas: The New Media Consortium, 2014. http://www.nmc.org/ publications/2014-horizon-report-higher-ed

McCabe, Bret. "Publish or Perish: Academic Publishing Confronts its Digital Future." Johns Hopkins Magazine. Fall 2013. http://hub. jhu.edu/magazine/2013/fall/future-of-academic-publishing

Pollett, Chris. "Reading Beyond the Lines: Volunteers Increase Pitts' Reach Around the World." 2012. http://www.candler. emory.edu/news/connection/summer2012/reading-beyond-thelines.cfm

Schonfeld, Roger C. and Rutner, Jennifer. Supporting the Changing Research Practices of Historians. ITHAKA S+R, December 12, 2012. http://www.sr.ithaka.org/sites/default/files/reports/ supporting-the-changing-research-practices-of-historians.pdf 